\title{
PENGENALAN PEDOMAN UMUM EJAAN BAHASA INDONESIA (PUEBI) DALAM MENGEMBANGKAN KEMAMPUAN BERBAHASA INDONESIA YANG BAIK DAN BENAR BAGI PARA GURU
}

\author{
Ahmad Muzaki, Chadis,, Yulia Agustin. \\ Pendidikan Bahasa Indonesia,Fakultas Bahasa dan Seni, \\ Universitas Indrapasta PGRI
}

\begin{abstract}
Abstrak
Bahasa Indonesia berkedudukan sebagai bahasa nasional dan bahasa negara. Artinya, bahasa Indonesia selain sebagai bahasa pemersatu antarwarga di Indonesia juga sebagai bahasa pengantar dalam dunia pendidikan. Lingkungan sekolah menjadi tempat berinteraksi dengan banyak orang yang ada di sekolah tersebut. Dengan adanya interaksi yang begitu banyak, dibutuhkan kosakata yang banyak pula, sehingga dibutuhkan kemampuan seseorang untuk lebih mengambangkan bahasanya. Sekolah memiliki peran penting dalam pengembangan bahasa Indonesia yang baik dan benar. Baik, sesuai situasi dan tujuan kegunaannya. Benar, sesuai dengan aturan dan pedoman yang berlaku. Saat ini, ada ejaan bahasa Indonesia terbaru yaitu PUEBI. Sekolah perlu mengetahui hal tersebut. Para warga sekolah wajib menerapkannya dalam rangka mengembangkan bahasa Indonesia yang baik dan benar. Oleh karena itu, kami mengenalkan ejaan PUEBI kepada guru-guru yang ada di SDN Setu 01 Pagi dan SDN Setu 02 Pagi dengan harapan mereka dapat terbiasa dengan adanya ejaan yang berlaku saat ini yaitu ejaan PUEBI.
\end{abstract}

Kata kunci: pelatihan, PUEBI

\begin{abstract}
Indonesian is located as a national language and the language of the country. That is, Indonesian is as a unifying language among citizens in Indonesia as well as the language of instruction in the world of education. The school environment is a place to interact with many people in the school. With so many interactions, a lot of vocabulary is also needed. So it takes a person's ability to further develop his language. Schools have an important role in the development of good and correct Indonesian. Good, according to the situation and purpose of its use. Right, according to the rules and guidelines that apply. At present, there is the latest Indonesian spelling, PUEBI. Schools need to know this. School members must apply it in order to develop good and correct Indonesian. Therefore, we introduce PUEBI spelling to teachers in Setu 01 Pagi Elementary School and Setu 02 Pagi Elementary School in the hope that they can get used to the current spelling of the PUEBI spelling.
\end{abstract}

Keywords: training, PUEBI

Correspondence author: Ahmad Muzaki, ahmadmuzaki8@gmail.com, Indonesia 


\section{PENDAHULUAN}

Kedudukan bahasa Indonesia sebagai bahasa negara memiliki fungsi sebagai bahasa pengantar dalam dunia pendidikan. Praktiknya, masyarakat dalam dunia pendidikan harus mengutamakan bahasa Indonesia sebagai bahasa percakapan di sekolah dalam situasi belajar mengajar. Pada umumnya masyarakat Indonesia yang pernah mengenyam pendidikan, meskipun hanya pendidikan dasar, menguasai dua bahasa, yaitu bahasa daerah dan bahasa Indonesia. Kemungkinan untuk menggunakan kedua bahasa itu sama besarnya dengan keluarga atau orang yang dari daerah lain.

Dalam situasi formal, urusan kedinasan, harus menggunakan bahasa Indonesia sebab bahasa Indonesia adalah bahasa resmi dan bahasa negara. Meskipun demikian, tampaknya kesempatan untuk menggunakan bahasa pertama, bahasa daerah, jauh lebih luas, daripada kesempatan untuk menggunakan bahasa Indonesia (Chaer, 2002: 4). Bahasa Indonesia yang baik adalah bahasa Indonesia yang digunakan sesuai dengan norma kemasyarakatan. Bahasa Indonesia yang benar adalah bahasa Indonesia yang digunakan sesuai dengan aturan atau kaidah bahasa Indonesia yang berlaku. (Matanggui dan Arifin, 205:13-14). Hal tersebut sangat penting ditanamkan pada warga masyarakat, terutama kepada anak- anak usia dini karena mereka dapat dengan cepat menyerap apa yang dipelajari daripada orang dewasa. Di sinilah, peran guru dirasa penting sebagai contoh utama anak didiknya. Mengingat, bahasa Indonesia selain sebagai bahasa pengantar dunia pendidikan juga merupakan mata pelajaran wajib diajarkan di sekolah.

Ejaan Bahasa Indonesia yang Disempurnakan (EYD) merupakan ejaan yang diberlakukan di Republik Indonesia semenjak tahun 1972 berdasarkan Keputusan Menteri Pendidikan dan Kebudayaan tanggal 27 Agustus 1975 Nomor 0196/U/1975 dan dipergunakan untuk menggantikan Ejaan Soewandi atau Ejaan Republik. Ejaan ini sudah beberapa kali direvisi yaitu tahun 1987 berdasarkan Keputusan Menteri Pendidikan dan Kebudayaan Nomor 0543a/U/1987 dan tahun 2009 berdasarkan Peraturan Menteri Pendidikan Nasional Nomor 46 Tahun 2009. Penyempurnaan terbaru dinamakan Pedoman Umum Ejaan Bahasa Indonesia (PUEBI) yang berdasar pada Peraturan Menteri Pendidikan dan Kebudayaan Nomor 50 Tahun 2015, telah diterbitkan pada tahun 2015 dan disebarkan melalui situs web resmi Kemendikbud tertanggal 21 Januari 2016. (https://ceritabahasa.co/2016/01/22/pedomanumum-ejaan-bahasa-indonesia-tahun-2015/)

Melihat gambaran di atas, dapat dianalisis bahwa kebutuhan akan pembelajaran bahasa Indonesia sangat diperlukan mengingat banyak mobilisasi yang terjadi di lingkungan sekolah. Komunikasi akan dilakukan dengan lancar apabila warga sekolah dapat menggunakan bahasa Indonesia yang baik dan benar. Jika dilihat dari keadaan geografisnya, sekolah SDN Setu baik 01 Pagi maupun 02 Pagi terletak jauh dari akses utama jalan raya. Untuk menempunhya harus berjalan kaki atau menggunakan motor. Lokasi sekolahnya pun dekat dengan pemukiman warga sekitar yang banyak berasal dari Betawi. Tentu untuk berkomunikasi mereka memerlukan lebih banyak pembelajaran bahasa Indonesia.

Berdasarkan hal tersebut, kami sebagai tim kegiatan bekerja sama dengan mitra kegiatan memberikan pengenalan PUEBI dalam mengembangkan bahasa Indonesia yang baik dan benar di dua sekolah yaitu, SDN Setu 01 Pagi dan SDN Setu 02 Pagi. 


\section{METODE PELAKSANAAN}

Metode yang digunakan dalam pengabdian masyarakat ini adalah metode ceramah plus yang dipadukan dengan diskusi, tanya-jawab, dan praktik. Selain itu, tim pelaksana akan melakukan pendampingan. Dengan penggunaan metode ini diharapkan pelatihan ini dapat berjalan dengan efektif dan efisien sehingga mencapai target kegiatan.

Kegiatan pengabdian masyarakat ini dilaksanakan pada Maret s.d. Juli 2018 di SDN Setu 01 Pagi dan SDN Setu 02 Pagi. Kedua SD ini terpilih sebagai tempat pelatihan karena berdasarkan hasil observasi dan survei terhadap guru-guru SD, informasi yang didapat yaitu mereka sangat minim tentang info terbaru terkait bahasa Indonesia, di antaranya PUEBI.

Beberapa alat-alat yang digunakan untuk menunjang pengabdian kepada masyarakat ini disediakan oleh pihak mitra dan beberapa disediakan oleh pihak tim. Alat- alat yang disediakan oleh pihak mitra adalah LCD proyektor dan komputer jinjing. Alat-alat yang disediakan oleh tim adalah buku tulis kecil, hand out pelatihan dan pendukung alat tulis lainnya.

\section{HASIL DAN PEMBAHASAN}

Pada awal kegiatan, kepala SDN 01 membuka kegiatan pengabdian masyarakat. Kepala sekolah memberikan arahan kepada guru-guru SDN 01 Pagi dan SDN 02 Pagi tentang pentingnya penenalan PUEBI. Pengenalan PUEBI dirasa sangat penting karena di dalam kegiatan belajar di kelas masih sangat minim penggunaan bahasa Indonesia yang baik dan benar.

Selanjutnya, Tim abdimas mengucapkan terima kasih kepada SDN 01 Pagi dan SDN 02 Pagi yang telah memberikan izin kepada tim untuk melaksanakan pengenalan PUEBI. Kedatangan tim abdimas disambut dengan baik. Dengan diadakannya kegiatan ini, diharapkan dapat membantu SDN 01 Pagi dan SDN 02 Pagi dalam mengenali PUEBI sehingga terciptanya penggunaan bahasa Indonesia secara baik dan benar.

Pada saat penyuluhan, tim abdimas menyampaikan materi pengenalan ejaan-ejaan yang ada di Indonesia. Guru-guru sangat antusias mengenai materi ejaan-ejaan yang kami sampaikan. Selain memberikan materi, kami pun memberikan contoh-contoh penggunaan kata-kata yang baku di dalam ejaan bahasa Indonesia. Selanjutnya, diadakan sesi tanya-jawab, diskusi untuk memaparkan PUEBI secara jelas. Perubahan serta perbedaa-perbedaan antara ejaan sebelum PUEBI. Setelah berjalannya diskusi, ternyata masih banyak guru-guru di SDN Setu 01 Pagi dan SDN Setu 02 Pagi yang belum mengenal PUEBI. Tim memberikan penjelasan disertai dengan contoh-contoh bahasa yang sering digunakan sehari-hari di lingkungan sekolah. 


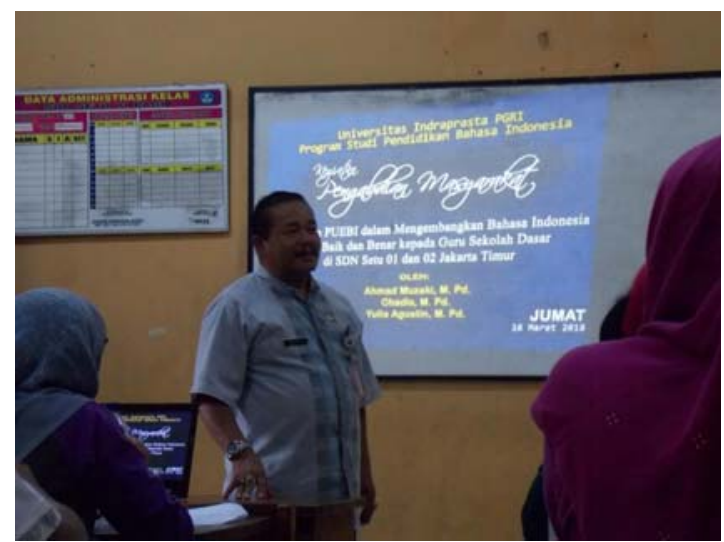

Gambar 1. Pelaksanaan Abdimas di SDN Setu 01 Pagi

Tim pelaksana abdimas melakukan arahan pada guru-guru untuk berperan aktif menggunakan bahasa Indonesia yang baku di dalam pengajaran di dalam kelas. Dengan seringnya menggunakan bahasa Indonesia yang baik dan benar, maka semua elemen sekolah akan mudah mengenali bahasa Indonesia yang baik dan benar.

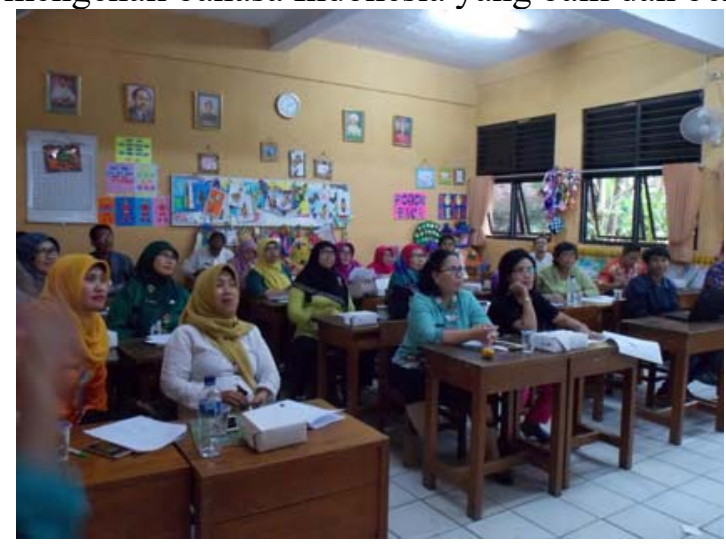

Gambar 2. Pelaksanaan Abdimas di SDN Setu 02 Pagi

Luaran dari kegiatan pengabdian masyarakat ini yaitu berupa buku saku pedoman penggunaan bahasa Indonesia yang baik dan benar. Dengan adanya buku saku tersebut diharapkan guru-guru di SDN Setu 01 Pagi dan SDN Setu 02 Pagi memiliki panduan di dalam mengajar sehari-hari, bahkan di dalam membuat soal-soal latihan pada saat ujian di sekolah.

Tujuan dari kegiatan pengabdian masyarakat ini, yaitu memberikan pengetahuan mengenai ejaan bahasa Indonesia yang saat ini menjadi PUEBI. Ejaan yang selama ini diketahui guru-guru di SDN Setu 01 Pagi dan SDN Setu 02 Pagi adalah ejaan yang disempurnakan (EYD). Padahal, ejaan saat ini menjadi PUEBI. Dengan adanya pengenalan ejaan terbaru saat ini, diharapkan masyarakat lebih mengenal PUEBI, terutama di lingkungan SDN Setu 01 Pagi dan SDN Setu 02 Pagi. Tim pelakasana kegiatan pengabdian masyarakat ini dilakukan oleh tiga orang dosen yang berasal dari lulusan pendidikan bahasa Indonesia. Lokasi pengenalan PUEBI ini dipilih di SDN Setu 01 Pagi dan SDN Setu 02 Pagi karena beberapa pertimbangan setelah ketua pengabdian masyarakat melakukan kunjungan ke sekolah. Dari hasil kunjungan, didapatkan keadaan masyarakat sekolah masih banyak yang belum mengenal PUEBI, bahkan percakapan sehari-hari pun masih menggunakan bahasa daerah. 


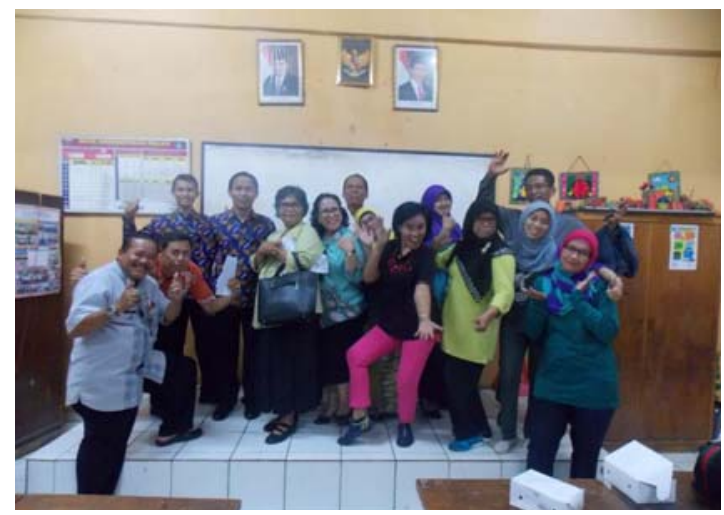

Gambar 3. Foto bersama guru-guru

Pada awal kunjungan tim pengabdian kepada masyarakat kepada kedua mitra adalah membicarakan tujuan, menentukan kesepakatan waktu kegiatan, dan menentukan tempat. Dari hasil kunjungan awal didapatkan kesepakatan mengenai tujuan diadakannya pengenalan PUEBI yaitu untuk menambah wawasan guru-guru di SDN Setu 01 Pagi dan SDN Setu 02 Pagi.

Luaran yang dihasilkan dari kegiatan pengabdian masyarakat ini adalah guru-guru di SDN Setu 01 Pagi dan SDN Setu 02 Pagi menjadi menambah wawsan mengenai ejaan bahasa Indonesia. Selain itu, luaran yang dihasilkan adalah buku saku yang berisi mengenai ejaan bahasa Indonesia. Luaran laian yang akan dihasilkan dari pengabdian masyarakat ini adalah artikel. Publikasi berupa artikel diharapkan masyarakat dapat mengetahui hasil dari kegiatan pengabdian masyarakat tersebut.

\section{SIMPULAN}

Adapun Simpulan dari hasil kegiatan Pengabdian kepada Masyarakat sebagai berikut:

1. Sosialisasi PUEBI ini sangat bermanfaat di dalam menambah wawasan guru di dalam proses pembelajaran di kelas.

2. Sosialisasi PUEBI disambut dengan antusias oleh semua guru SDN Setu 01 Pagi dan SDN 02 Setu Pagi. Mereka menyadari di dalam membuat soal-soal ujian siswa masih banyak menggunakan bahasa yang tidak baku.

3. Kegiatan pengabdian kepada masyarakat disambut positif oleh semua peserta, hal ini ditandai dengan antusias dan banyak peserta memanfaatkan waktu untuk bertanya mengenai materi yang saat itu dijelaskan; dan

4. Peserta kegiatan merasa senang mendapat ilmu baru tentang berbagai metode pengenalan PUEBI.

\section{DAFTAR PUSTAKA}

Chaer, A. (2002). Pembakuan Bahasa Indonesia. Jakarta: Rineka Cipta.

Matanggui, J. dan Arifin, E. Z. (2015). Analisis Kesalahan Berbahasa Imdonesia. Jakarta: Pustaka Mandiri.

https://Cerita Bahasa. (2016). Pedoman Umum Ejaan Bahasa Indonesia. (Diperoleh 27 Desember 2016) 